\title{
A Regional Panorama of Dysferlinopathies
}

\section{Disferlinopatilerin Bölgesel Panoraması}

\author{
Gülden DiNiz'1, Gaye ERYAŞAR², Sabiha TÜRE², Ayfer AKÇAY³, Ragıp ORTAÇ', Hasan TEKGÜL³, \\ Galip AKHAN ${ }^{4}$
}

${ }^{1}$ Department of Pathology, Dr. Behçet Uz Children's Hospital, IZMIR, TURKEY, ${ }^{2}$ Department of Neurology, Izmir Atatürk Education Hospital, IZMiR, TURKEY, ${ }^{3}$ Department of Pediatric Neurology, Ege University, Faculty of Medicine, IZMIR, TURKEY and

${ }^{4}$ Department of Neurology, Katip Çelebi University, Faculty of Medicine, IZMIR, TURKEY

\begin{abstract}
Objective: We describe the characteristic features of 11 patients (6 men and 5 women) with dysferlinopathies confirmed by muscle biopsies. In addition, we aimed to provide a realistic comprehensive picture of the severe muscle diseases in the Aegean Region of Turkey.

Material and Method: We retrospectively reviewed 90 patients who underwent muscle biopsy examinations between 2008 and 2011 in the pathology laboratory of Izmir Dr.Behcet Uz Children's Hospital. Biopsy specimens of all patients clinically diagnosed as muscular dystrophy referred from 4 different centers of neurological disorders were collected.
\end{abstract}

Results: Dystrophinopathy was the most $(n=45)$ and gammasarcoglycanopathy was the second common $(n=13)$ muscular dystrophy in this series. The mean age of all 90 patients was 8.8 years ( 3 months- 64 years). Only 14 cases (15.5\%) were older than 14 , and 23 cases were younger than two years. Dysferlinopathy was the most common dystrophy in the older age group. There were statistical significant differences between the types of dystrophy and inflammation (0.021), creatine kinase levels $(\mathrm{p}=0.001)$, age $(\mathrm{p}=0.001)$, and gender $(\mathrm{p}<0.001)$ of the patients.

Conclusion: The present study revealed that dysferlinopathies is not an uncommon form of muscular dystrophies in western Turkey. We have concluded that if avoidance from unnecessary therapeutic interventions is desired, we must be aware of the relative frequencies of dysferlinopathies.

Key Words: Muscular dystrophies, Muscle cells, Immunohistochemistry

\section{INTRODUCTION}

Dysferlin (DYSF), the protein product of the DYSF gene, is a $237 \mathrm{kDa}$ transmembrane protein involved in calciumdependent sarcolemma resealing and plays an important role in muscle fiber repair (1). It is encoded by dysferlin gene (DYSF) mapped on chromosome 2p13 (2). Thirteen years ago the DYSF gene was firstly cloned and identified as the gene mutated in limb girdle muscular dystrophy

(Turk Patoloji Derg 2012, 28:259-265)

Received : 02.07.2012 Accepted : 13.08.2012

\section{ÖZ}

Amaç: Bu çalışmada, kas biyopsi incelemesiyle disferlinopati olduğu doğrulanan 11 olgunun ( 6 erkek ve 5 kadın) klinik ve histopatolojik özelliklerini sunduk. Ek olarak Türkiye’nin Ege Bölgesinde karşılaşılan distrofik kas hastalıklarının gerçekçi ve kapsamlı bir dökümünü yapmayı amaçladık.

Gereç ve Yöntem: 2008 ve 2011 yılları arasında Dr. Behçet Uz Çocuk Hastanesi, Patoloji Laboratuvarında kas biyopsi incelemesi yapılan 90 hasta retrospektif olarak değerlendirildi. Tüm hastalar klinik olarak muskuler distrofi tanısı almıştı ve biyopsi materyalleri 4 farklı nörolojik hastalıklar merkezinden gönderilmişti.

Bulgular: $\mathrm{Bu}$ seride, distrofinopatiler en sik $(\mathrm{n}=45)$, gama sarkoglikanopatiler ikinci sıklıkta $(n=13)$ gözlendi. Tüm hastalarda ortalama yaş 8,8 yıldı (3 ay - 64 yıl). Yalnızca 14 olgu $(\% 15,5) 14$ yaşından büyük, 23 olgu $(\% 25,5) 2$ yaşından küçüktü. Disferlinopati erişkin yaş grubunda en sık gözlenen muskuler distrofiydi. Muskuler distrofi subtipi ile inflamasyon varlığ $1(\mathrm{p}=0,021)$, kreatin kinaz düzeyi $(\mathrm{p}=0,001)$, hastaların yaşı $(\mathrm{p}=0,001)$ ve cinsiyeti $(\mathrm{p}<0.001)$ arasında istatistiksel olarak anlamlı ilişki saptandı.

Sonuç: Bu çalışma, disferlinopatilerin Türkiye’nin batısında gözlenen muskuler distrofilerin çok da nadir bir tipi olmadığını ortaya sermiştir. Bizler; gereksiz terapötik girişimlerden kaçınmak arzu ediliyorsa, disferlinopatilerin göreceli sıklığının farkındalığının şart olduğunu vurgulamaya çalıştık.

Anahtar Sözcükler: Musküler distrofi, Kas hücreleri, İmmünohistokimya

(LGMD) type 2B, Myoshi Myopathy (MM) and distal anterior compartment myopathy (3-5).

Early studies have shown that the DYSF gene is a huge gene composed of 55 exons that span $233 \mathrm{kbp}$ and 6243 coding bp of genomic DNA (6). More than 300 different sequence variants have been reported to date and some of these variants manifest nonpathogenic polymorphism (6). The variations are spread along the entire coding sequence,

Correspondence: Gülden DİNİZ.PhD

Department of Pathology, Dr. Behçet Uz Children’s Hospital,

IZMMIR, TURKEY

E-mail: agdiniz@gmail.com Phone: +90 2324895656 
without any apparent mutational "hotspot" $(1,4,6)$. Molecular genetic analysis is therefore not cost effective for screening dysferlinopathies.

Dysferlinopathies are autosomal recessive muscular diseases caused by DYSF mutations, which lead to a reduced amount or a complete lack of dysferlin in skeletal muscle. The monoclonal antibody to dysferlin has recently been developed and immunolabelling with this antibody reveals a dysferlin polypeptide on the plasma membrane of skeletal muscle. A specific loss of dysferlin labeling was observed in patients with mutations in the DYSF gene. In other words, diagnosis of dysferlinopathies is dependent on demonstration of this deficiency in skeletal muscle or blood monocytes (7-10).

Awareness of relative frequency and clinical variability of dysferlinopathies is essential for accurate differential diagnosis and for avoidance from unnecessary and potentially hazardous therapeutic interventions. In this study, we aimed to evaluate the spectrum of morphologic changes in immunohistochemically proven cases of dysferlinopathies and to correlate the findings with the clinical phenotype. In addition, we tried to provide a realistic comprehensive picture of muscular dystrophies and determine the frequency of dysferlinopathy in western Turkey.

\section{MATERIAL and METHODS}

The study was performed in the Pathology Laboratory of the Izmir Dr. Behcet Uz Children's Hospital from January 2008 through December 2011. A total of 90 patients with severe muscle disease were evaluated retrospectively. All of them had been diagnosed as muscular dystrophy on the basis of muscle biopsy findings. Severe alterations of myofiber size and shape, splitting, increase in number of internal nuclei, fiber type disproportions, necrosis, myophagocytosis, regeneration and fibrosis were simply classified as muscular dystrophy. The individual patient database was reviewed in all cases and detailed clinical information of the patients was recorded including age, functional ability associated complaints like muscle weakness and respiratory distress, detailed family history and consanguinity. Neurological examination and laboratory findings were also evaluated. Laboratory evaluations included measurements of serum creatine kinase $(\mathrm{CK})$, serum aspartate aminotransferase (AST) levels, nerve conduction times, and electromyographic (EMG) examinations. Most of the muscle biopsies were obtained from gastrocnemius muscle $(n=85)$. The remaining biopsies were from the deltoid muscle.

Samples were frozen in isopentane cooled in liquid nitrogen and 8 to 12 - micron sections were cut using cryostat. Slides were stained with hematoxylin\&eosin, Gomori's trichrome, modified Gomori's trichrome (Engel-Cunningham modification), oil red-O, Periodic Acid Shiff (PAS), d-PAS, crystal violet stains. In enzyme histochemical techniques we used nicotinamide adenine dinucleotide tetrazolium reductase (NADH-TR), succinate dehydrogenase (SDH), cytochrome oxidase (COX) and combined COX- SDH stains. Spectrin (Novo-castra, UK, NCL-spec1), dystrophin N-terminus (Novo-castra, UK, NCL-dys3), adhalin (Novocastra, UK, NCL-a-sarc), other sarcoglycans (beta, delta, gamma; Novo-castra, UK, NCL-b-d-g-sarc), laminin alpha-2 chain (Novo-castra, UK, NCL-merosin), myotilin (Novo-castra, UK, NCL-myotilin), collagen VI (Novocastra, UK, NCL-COLL-VI), $\beta$-dystroglycan (Novocastra, UK, NCL-b-DG), HLA Class 1 (Novo-castra, UK, NCL-HLA-ABC), NCAM (ThermoScientific, CA, USA, CD56), nitric oxide Synthase-1 (Novo-castra, UK, NCLNOS-1), emerin (Novo-castra, UK, NCL-emerin), caveolin 3 (Novus Biologicals, CA, USA, NB110-5029), calpain 3 (Abcam, Cambridge, UK, ab103250) and dysferlin (Novo-castra, UK, NCL-Hamlet-2) antibodies were used for immunohistochemical analyses. Myosin heavy chain fast (Novo-castra, UK, NCL-MHCf) antibody was used for discriminating between fiber types, and myosin heavy chain neonatal (Novo-castra, UK, NCL-MHCn) antibody was used for identification of immature fibers. Monoclonal antibodies against T-cells (CD3), B-cells (CD 20), macrophages (CD68), suppressor T cells (CD8) and helper $\mathrm{T}$ cells (CD4) were used in selected cases for the identification of the inflammatory cell spectrum.

The Mann-Whitney $\mathrm{U}$ and chi-square tests were used for the comparison between groups. P values less than 0.05 were considered to be statistically significant.

\section{RESULTS}

Dystrophinopathies were the most common (50\%, $\mathrm{n}=45$ ) muscular dystrophies, followed by gamma sarcoglycanopathies $(14.4 \%, \mathrm{n}=13)$, dysferlinopathies $(12.3 \%, \mathrm{n}=11)$ and merosin negative congenital muscular dystrophies (CMD) $(5.3 \%, n=6)$ in decreasing order of frequency (Table I). The mean age of all 90 patients was 8.8 \pm 10.7 years ( 3 months- 64 years). Only 14 cases (15.5\%) were older than 14 years and 23 (26\%) cases were younger than two years. Dysferlinopathy was the most common muscular dystrophy in the older (78.5\%) age group and merosin negative CMD (26.1\%) was the most common dystrophy in the infantile age (0-2 years) group. In MannWhitney $U$ and chi-square tests, there were statistically significant differences between the types of muscular 
Table I: The detailed clinical characteristics of the patients

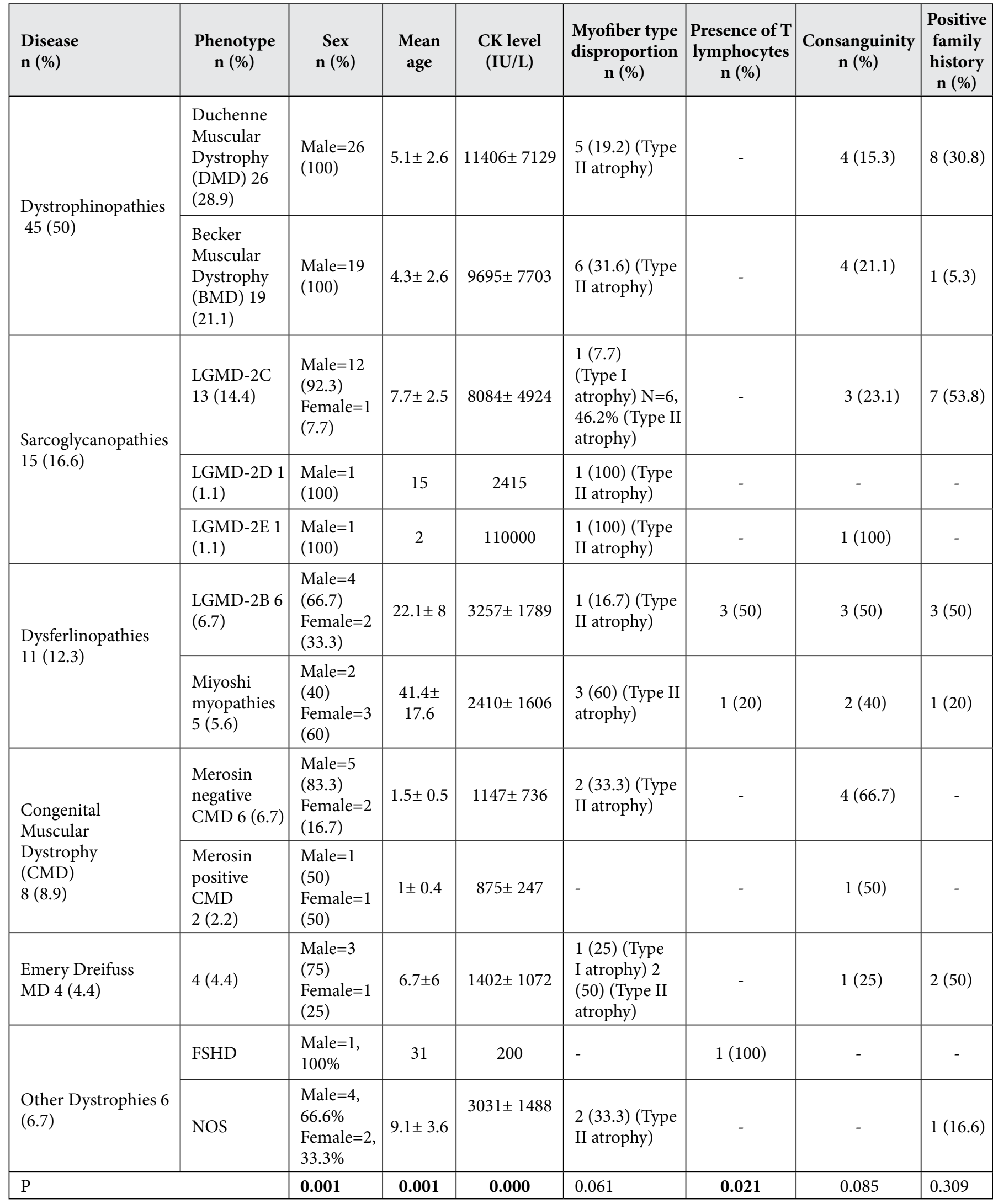


dystrophy and the presence of inflammatory infiltration $(\mathrm{p}=0.021)$, CK levels $(\mathrm{p}=0.001)$, age $(\mathrm{p}=0.001)$ and gender $(\mathrm{p}<0.001)$ of the patients.

The mean age of the patients with dysferlinopathies was $30.9 \pm 16.03$ years, ranging from 14 to 64 years. The patients with LGMD phenotypes were younger than MM patients, without any statistically significant difference as estimated by Mann- Whitney U test $(\mathrm{p}=0.082)$. Detailed clinical characteristics of the patients are presented in Table 1. All patients presented some degree of muscle weakness. Ten of them (90.9\%) had high CK levels. At least one of the muscle serum enzymes was altered in all patients. Four patients (36.4\%) had similarly affected family members. The consanguinity rate was $45.5 \%(n=5)$. Physical examination at the time of diagnosis especially revealed weakness of limb muscles in most patients. Needle electromyogram was performed and all patients were classified as myopathic. The final diagnosis was assigned on the basis of muscle biopsy findings.

Clinically, the majority had the LGMD phenotype (54.5\%) with proximal muscle involvement and others had the MM phenotype (45.5\%) with distal involvement. Tibial muscle phenotypes were not encountered. Morphologically, lobulated fibers were noted in a patient with $M M$ (Figure 1). The presence of inflammation had preference to a particular phenotype and most patients with remarkable inflammation had the LGMD phenotype (Figure 2). The inflammatory reaction was predominantly comprised of macrophages (Figure 3) and T-lymphocytes (Figure 4). Three of these cases were diagnosed as inflammatory myositis with previous muscle biopsy specimens examined in other pathology laboratories. Significant type II myofiber atrophy was noted in 4 patients $(36.4 \%)$ and 3 of them had the Myoshi phenotype with longer duration of illness (Figure 5). Immunostaining to dysferlin showed total absence of labeling along the membrane in all cases (Figure 6). Normal immunolabeling was noted to the rest of the antibodies in all, except in three cases which showed reduced intensity to calpain-3 expression.

\section{DISCUSSION}

A protective membrane resealing mechanism at the cell level is mediated by exocytosis of intracellular vesicles forming a membrane "patch" at the disruption site. This process requires participation and coordination of a large group of proteins involving cytoskeleton remodeling, vesicle translocation, and membrane fusion (11). Some of these proteins have recently been discovered and linked to some human muscle diseases (12). According to the "patch

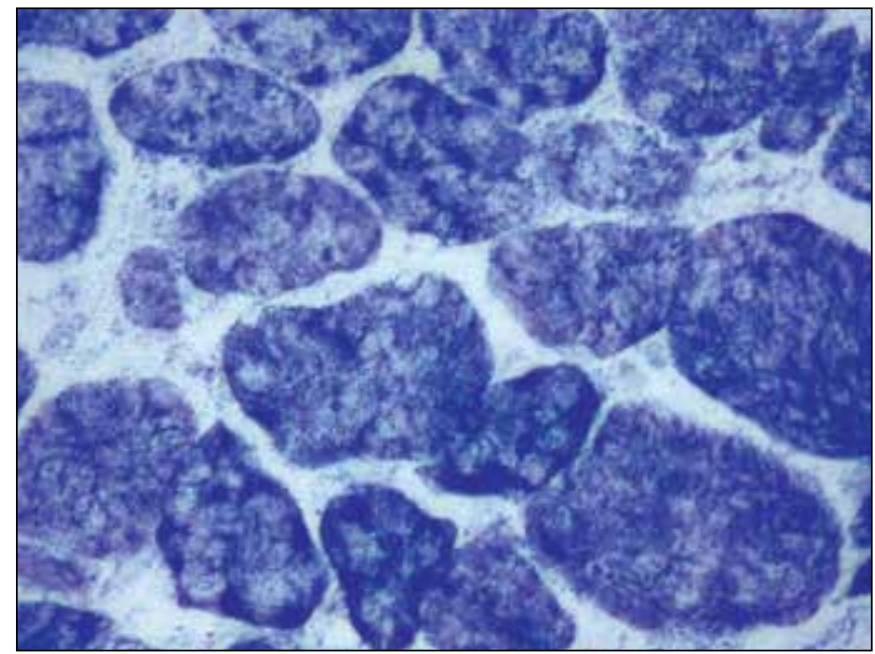

Figure 1: Trabecular (lobulated) fiber in a MM case (SDH, x200).

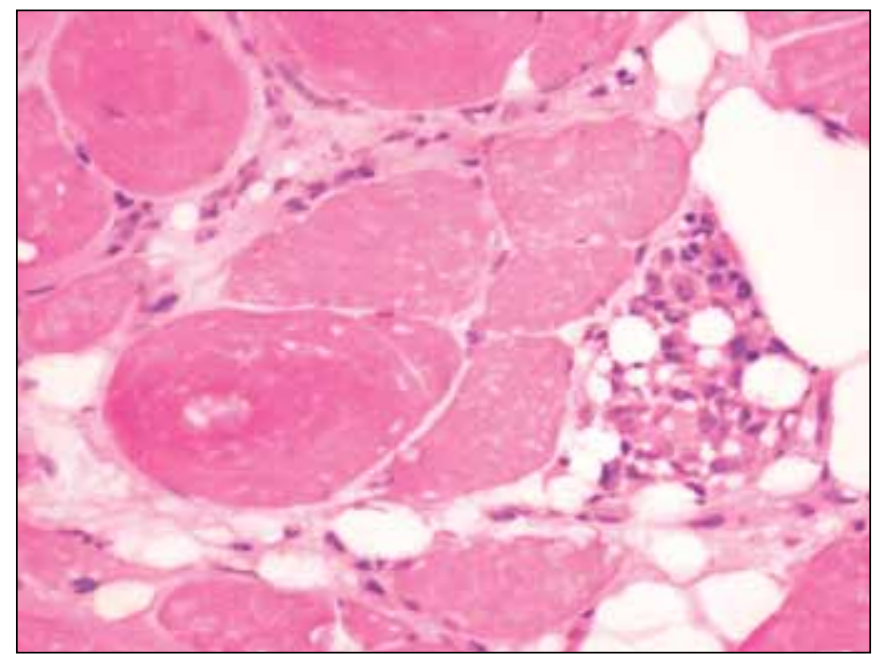

Figure 2: Dense inflammation was detected in some cases and hence a differential diagnosis of polymyositis was made $(\mathrm{H} \& \mathrm{E}$, $\mathrm{x} 400)$.

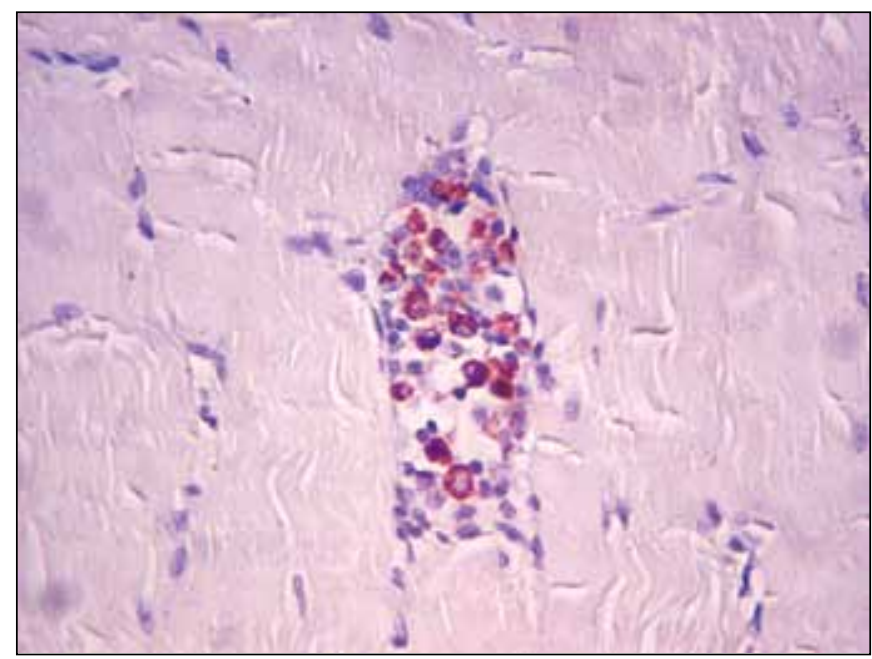

Figure 3: Inflammatory inflammation was comprised predominantly macrophages with anti-CD68 antibody (x400). 


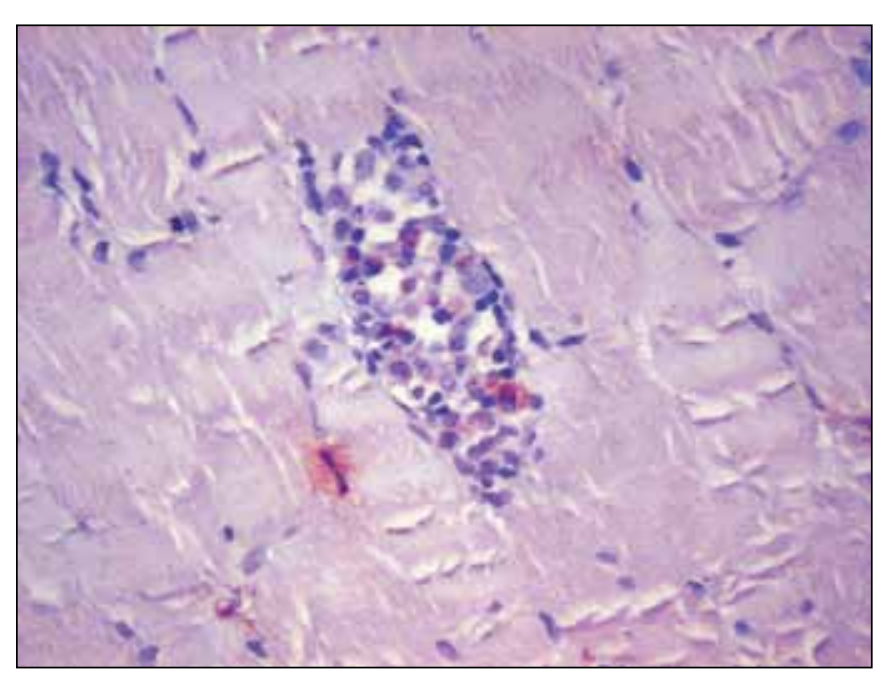

Figure 4: T-lymphocytes also were seen in the inflammation with anti-CD3 antibody (x400).

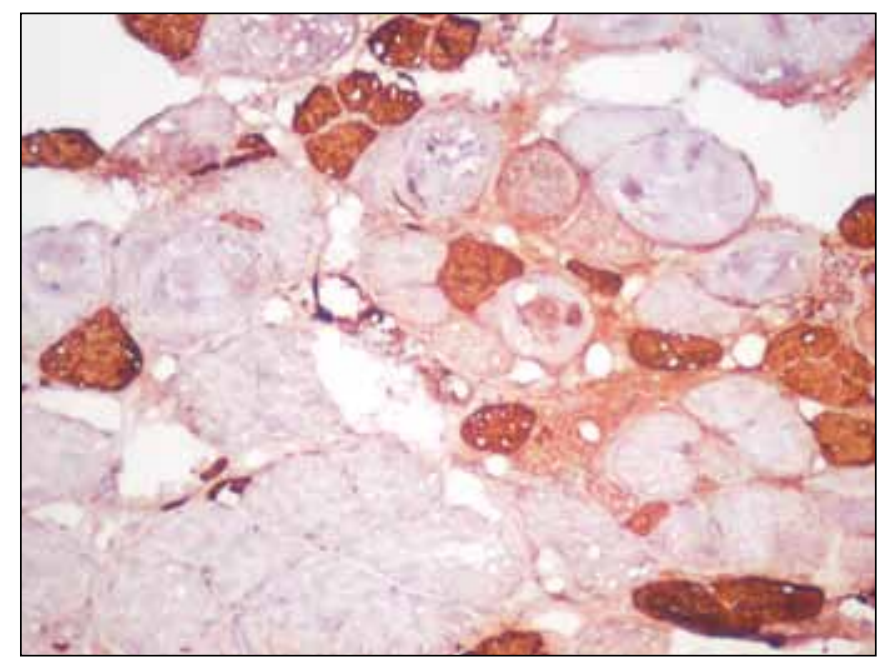

Figure 5: Remarkable type II myofiber atrophy in dysferlinopathy with anti MHCf antibody (x100).

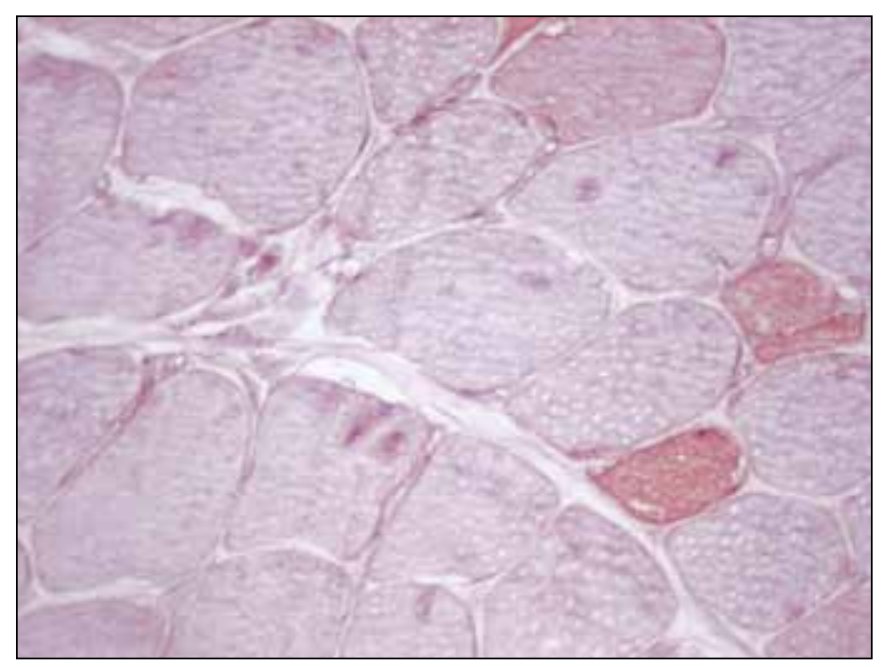

Figure 6: Dysferlin deficiency along the cell membrane with anti dysferlin antibody (x200). hypothesis", membrane repair requires accumulation and fusion of vesicles with each other and plasma membrane at the site of disruption, wherein dysferlin also acts as a mediator in this process. Dysferlin has been shown to play roles in muscle membrane repair and muscle regeneration, both of which require vesicle-membrane fusion $(9,13)$. Ultrastructural evidence suggests that membrane repair mechanism is affected by dysferlin deficiency resulting in muscle fiber damage, even though vesicle formation is determined $(9,13)$. However, the mechanism by which muscle becomes dystrophic in these disorders remains poorly understood (1-13). While clinical findings in the present study were heterogeneous in terms of site of muscle involvement, age of onset, rate of progression, all histopathological examinations showed the classical signs of a muscular dystrophy including an increase in fiber size variation, foci of necrosis and regeneration. Regeneration was especially prominent and we have observed a large number of immature fibers by immunhistochemical staining using anti-MHC neonatal antibody. This finding also reinforced the role of dysferlin in the maturation of regenerating fiber.

Identical mutations in the dysferlin gene can produce more than one myopathy phenotype such as limb girdle dystrophy, distal myopathy and distal myopathy with anterior tibial onset (DMAT). Muscle weakness in LGMD2B starts in the proximal muscles of the pelvic girdle and presents difficulties with running and climbing stairs. In contrast, initial muscle weakness in $\mathrm{MM}$ is characteristically restricted to the gastrocnemius muscle, as indicated by an inability to stand on the toes $(3,4,14,15)$. The finding that both these conditions are caused by mutations in the same gene is interesting because muscular dystrophies are defined by the muscles involved and the possibility of such different patterns of muscle involvement is unique among known dystrophies (3). For example, Duchenne and Becker muscular dystrophies have different clinical profiles yet the actual muscle involvement is identical in both cases (3). This certainly raises the possibility that dysferlin may interact with a modifying protein that is the product of another gene (3). For example it is known that reducing calpain 3 expressions is often accompanied by dysferlinopathies, but concomitant mutations are not determined in the calpain 3 gene (16). It is also possible that dysferlin plays a role in the development of the distal and proximal musculature in the fetus. Interestingly since different muscle groups are the initial targets, these diseases have been considered as two distinct clinical conditions (4-7). Analysis of human fetal tissue showed that dysferlin is being expressed at the 
earliest stages of the development when the limbs start to show regional differentiation (3). Anderson et al. supposed that lack of dysferlin at the critical time of embryogenesis may contribute to the pattern of muscle involvement that develops later with the onset of a muscular dystrophy $(1,3,7,14,15)$. In our series, 6 patients had the LGMD and 5 patients had the MM phenotype and there were no cases with anterior tibial myopathy. The patients with proximal involvement have presented the diseases with its earlier onset. In our series the mean age for the LGMD phenotype was much lower (22.1 \pm 8 years; 14 - 34 years) in consistent with literature findings. In addition, we determined the reduced intensity of calpain 3 expressions in only three cases.

Skeletal muscle also requires an efficient and active membrane repair system to overcome the harmful effects of contractions (11-13). An acute membrane repair mechanism not only prevents damaged cells from necrosis, but also reduces the "danger" signals exposed by the immune system, which will otherwise amplify and cause massive tissue injury (11-13). However, "danger" signals are attenuated and inflammatory cells except macrophages do not emerge in most types of muscular dystrophies. Infiltrates of T lymphocytes have been previously described in only two types of muscular dystrophies, dysferlin deficiency and facioscapulohumeral dystrophy (FSHD) (9). Although muscle inflammation is widely recognized in dysferlinopathy, the contribution of the immune system to the pathology of dysferlinopathy remains to be fully explored. While it is widely accepted that MHC-class 1 expression is up-regulated in inflammatory myopathies, it is not clear whether it is a result of the nonspecific response to muscle degeneration or of the specific disease process itself (17). Previous reports have shown that MHC-class 1 is induced by several proinflammatory cytokines which are highly expressed in inflammatory myopathies. Normally MHC class 1 is not expressed on the sarkolemma of both normal and myopathic muscle cells. Its increased expression is observed in patients with chronic inactive inflammatory myopathy as well as with active inflammatory myopathy. It is detectable even after the initiation of immunosuppressive treatment (17). Contrarily, MHC-Class I complex is not over-expressed in dysferlinopathies. Therefore, immunostained MHC class 1 complex is a valuable marker for differential diagnosis. As well as in dysferlinopathies, there is evidence of immune system involvement in muscle inflammation and downregulation of the complement inhibitor factor, CD55 $(11,18,19)$. In this study, diffuse inflammatory infiltrates or other evidences of inflammatory processes were noted in four patients. However, over expression of MHC class 1 complex was not detected in any of them. Molecular genetic studies to determine the type of mutation involved in inflammation were not performed in our cases. Immunophenotyping of inflammatory infiltrates in our study revealed predominantly macrophages and $\mathrm{T}$ cells. There was no statistically significant difference between phenotype of dysferlinopathies and the presence of inflammation $(p=0.429)$. In addition there was no correlation between the duration of illness and density of inflammatory infiltration.

Misdiagnosis is common place in patients with primary dysferlinopathy. More dramatically, it can lead to unnecessary and potentially hazardous therapeutic interventions such as long-term oral administration of corticosteroids or immune suppressors (20). In a couple of retrospective studies, nearly $25 \%$ of LGMD $2 \mathrm{~B} / \mathrm{MM}$ patients had initially been diagnosed with polymyositis, one of the most common dysimmune inflammatory myopathy in adults (18-21). In our series, 3 patients (27.2\%) were also diagnosed as inflammatory myopathies with previous biopsies. In dysferlinopathy, inflammatory changes in muscle are sometimes so florid that they can mislead the pathologist as well as the clinician. Moreover, CK levels are equally elevated in both conditions, a finding which also adds to the confusion. When faced with similar challenges, it is best to systematically perform additional immunostainings in order to differentiate the two conditions (20). Preliminary clinical ascertainment is crucial and generally provides relevant clues to the diagnosis of dysferlinopathy. The distal limb muscle involvement in the clinical picture is quite suggestive for MM and is often confirmed by calf muscle imaging. A total absence of dysferlin in monocytes and/or in muscle is a key element for the accurate diagnosis. Even better is to detect a homozygous mutation in the DYSF gene. In any event, the most critical clue will be generated by dysferlin immunohistochemistry and immunoblotting.

In conclusion, our study reveals dysferlinopathies to be a common (12.3\%) identifiable cause of severe muscle diseases next to gamma sarcoglycanopathies in western Turkey. The overall prevalence of dysferlinopathies is still hard to estimate in the absence of a comprehensive international patients' registry. Immunohistochemistry helps in the discrimination from other forms of LGMD and immunohistochemistry can also be used to identify dysferlinopathy. In cases of suspected dysferlin deficiency, the large size of the dysferlin gene discourages molecular testing. Although it is generally agreed that an extensive molecular analysis has a high cost, a precise determination 
of the dysferlin gene is important for genetic counseling and in shaping future therapeutic strategy. Genetic analysis for screening dysferlinopathies is not cost effective but this analysis will also help identify the types of mutations in Turkey and explain the high regional dysferlinopathy prevalence.

\section{REFERENCES}

1. Cacciottolo M, Numitone G, Aurino S, Caserta IR, Fanin M, Politano L, Minetti C, Ricci E, Piluso G, Angelini C, Nigro $V$ : Muscular dystrophy with marked Dysferlin deficiency is consistently caused by primary dysferlin gene mutations. Eur J Hum Genet 2011, 19:974-980

2. Bashir R, Britton S, Strachan T, Keers S, Vafiadaki E, Lako M, Richard I, Marchand S, Bourg N, Argov Z, Sadeh M, Mahjneh I, Marconi G, Passos-Bueno MR, Moreira Ede S, Zatz M, Beckmann JS, Bushby K: A gene related to Caenorhabditis elegans spermatogenesis factor fer-1 is mutated in limb-girdle muscular dystrophy type 2B. Nat Genet 1998, 20:37-42

3. Anderson LV, Davison K, Moss JA, Young C, Cullen MJ, Walsh J, Johnson MA, Bashir R, Britton S, Keers S, Argov Z, Mahjneh I, Fougerousse F, Beckmann JS, Bushby KM: Dysferlin is a plasma membrane protein and is expressed early in human development. Hum Mol Genet 1999, 8:855-861

4. Eryaşar G, Seçil Y, Beckmann Y, İnceoğlu Kendir A, Diniz AG, Başoğlu M: İki olgu nedeniyle disferlinopati. Türk Nörol Derg 2011, 17: 45-50

5. Klinge L, Aboumousa A, Eagle M, Hudson J, Sarkozy A, Vita G, Charlton R, Roberts M, Straub V, Barresi R, Lochmüller H, Bushby K: New aspects on patients affected by dysferlin deficient muscular dystrophy. J Neurol Neurosurg Psychiatry 2010, 81: 946-953

6. Krahn M, Béroud C, Labelle V, Nguyen K, Bernard R, Bassez G, Figarella-Branger D, Fernandez C, Bouvenot J, Richard I, Ollagnon-Roman E, Bevilacqua JA, Salvo E, Attarian S, Chapon F, Pellissier JF, Pouget J, Hammouda el H, Laforêt P, Urtizberea JA, Eymard B, Leturcq F, Lévy N: Analysis of the DYSF mutational spectrum in a large cohort of patients. Hum Mutat 2009, 30:E345-375

7. Liu J, Aoki M, Illa I, Wu C, Fardeau M, Angelini C, Serrano C, Urtizberea JA, Hentati F, Hamida MB, Bohlega S, Culper EJ, Amato AA, Bossie K, Oeltjen J, Bejaoui K, McKenna-Yasek D, Hosler BA, Schurr E, Arahata K, de Jong PJ, Brown RH Jr: Dysferlin, a novel skeletal muscle gene, is mutated in Miyoshi myopathy and limb girdle muscular dystrophy. Nat Genet 1998, 20:31-36

8. Wein N, Krahn M, Courrier S, Bartoli M, Salort-Campana E, Nguyen K, Fernandez C, Pouget J, Fossat C, Depetris D, Leturcq F, Cau P, Levy N: Immunolabelling and flow cytometry as new tools to explore dysferlinopathies. Neuromuscul Disord 2010, 20:57-60

9. Gayathri N, Alefia R, Nalini A, Yasha TC, Anita M, Santosh V, Shankar SK: Dysferlinopathy: Spectrum of pathological changes in skeletal muscle tissue. Indian J Pathol Microbiol 2011, 54: 350-354
10. Meznaric M, Gonzalez-Quereda L, Gallardo E, de Luna N, Gallano P, Fanin M, Angelini C, Peterlin B, Zidar J: Abnormal expression of dysferlin in skeletal muscle and monocytes supports primary dysferlinopathy in patients with one mutated allele. Eur J Neurol 2011, 18:1021-1023

11. Han R: Muscle membrane repair and inflammatory attack in dysferlinopathy. Skelet Muscle 2011, 1:10

12. Grounds MD, Shavlakadze T: Growing muscle has different sarcolemmal properties from adult muscle: a proposal with scientific and clinical implications: reasons to reassess skeletal muscle molecular dynamics, cellular responses and suitability of experimental models of muscle disorders. Bioessays 2011, 33:458-468

13. Chiu YH, Hornsey MA, Klinge L, Jørgensen LH, Laval SH, Charlton R, Barresi R, Straub V, Lochmüller H, Bushby K: Attenuated muscle regeneration is a key factor in dysferlindeficient muscular dystrophy. Hum Mol Genet 2009, 18: 1976-1989

14. Klinge L, Dean AF, Kress W, Dixon P, Charlton R, Müller JS, Anderson LV, Straub V, Barresi R, Lochmüller H, Bushby K: Late onset in dysferlinopathy widens the clinical spectrum. Neuromuscul Disord 2008, 18:288-290

15. Rosales XQ, Gastier-Foster JM, Lewis S, Vinod M, Thrush DL, Astbury C, Pyatt R, Reshmi S, Sahenk Z, Mendell JR: Novel diagnostic features of dysferlinopathies. Muscle Nerve 2010, 42:14-21

16. Anderson LV, Harrison RM, Pogue R, Vafiadaki E, Pollitt C, Davison K, Moss JA, Keers S, Pyle A, Shaw PJ, Mahjneh I, Argov Z, Greenberg CR, Wrogemann K, Bertorini T, Goebel HH, Beckmann JS, Bashir R, Bushby KM: Secondary reduction in calpain 3 expression in patients with limb girdle muscular dystrophy type $2 \mathrm{~B}$ and Miyoshi myopathy (primary dysferlinopathies). Neuromuscul Disord 2000, 10:553-559

17. Choi JH, Park YE, Kim SI, Kim JI, Lee CH, Park KH, Kim DS: Differential immunohistological features of inflammatory myopathies and dysferlinopathy. J Korean Med Sci 2009, 24: 1015-1023

18. Lerario A, Cogiamanian F, Marchesi C, Belicchi M, Bresolin N, Porretti L, Torrente Y: Effects of rituximab in two patients with dysferlin-deficient muscular dystrophy. BMC Musculoskelet Disord 2010, 11:157

19. Han R, Frett EM, Levy JR, Rader EP, Lueck JD, Bansal D, Moore SA, Ng R, Beltrán-Valero de Bernabé D, Faulkner JA, Campbell KP: Genetic ablation of complement C3 attenuates muscle pathology in dysferlin-deficient mice. Clin Invest 2010, 120: 4366-4374

20. Nguyen K, Bassez G, Krahn M, Bernard R, Laforêt P, Labelle $V$, Urtizberea JA, Figarella-Branger D, Romero N, Attarian S, Leturcq F, Pouget J, Lévy N, Eymard B: Phenotypic study in 40 patients with dysferlin gene mutations: high frequency of atypical phenotypes. Arch Neurol 2007, 64:1176-1182

21. Urtizberea JA, Bassez G, Leturcq F, Nguyen K, Krahn M, Levy N: Dysferlinopathies. Neurol India 2008, 56:289-297 